\title{
SPEED, ALCOHOL AND SAFETY BELTS AS IMPORTANT FACTORS INFLUENCING THE NUMBER OF FATALITIES IN ROAD ACCIDENTS IN THE VOIVODSHIPS
}

\author{
PRĘDKOŚĆ, ALKOHOL I PASY BEZPIECZEŃSTWA \\ JAKO ISTOTNE CZYNNIKI WPLYWAJĄCE NA LICZBE \\ OFIAR ŚMIERTELNYCH WYPADKÓW DROGOWYCH \\ NA OBSZARZE WOJEWÓDZTW
}

\section{Joanna Wachnicka, Kazimierz Jamroz}

Department of Highway Engineering, Faculty of Civil Engineering and Environment, Gdansk University of Technology, ul. Narutowicza 11, 90-952 Gdansk, Polska joanna.wachnicka@wp.pl, kjamroz@pg.gda.pl,

Abstract. Regions are the basic units of management in the European Union. So far factors influencing road safety in the regions have been little recognised. Based on literature review, some factors affecting traffic safety in the EU regions have been identified. Then data available on the voivodships in Poland in 2000-2004 have been gathered. The gathered data have been analysed and the most important factors influencing the number and effects of road accidents have been identified. The following paper presents preliminary results of a wider research programme on road safety in the areas of the voivodships.

Key words: regions, road traffic safety, impact factors, modelling

Streszczenie. Regiony stanowia podstawowa jednostę zarzadzania w Unii Europejskiej. Jak dotad mało rozpoznanym problemem sa czynniki wpływajce na bezpieczeństwo ruchu drogowego. na obszarze regionów. Na podstawie przeglądu literatury zidentyfikowano niektóre czynniki wpływajace na bezpieczeństwo ruchu na obszarze regionów w UE. Nastepnie zebrano dane dostępne dla województw $w$ Polsce $w$ latach 2000-2004. Przeanalizowano zebrane dane $i$ zidentyfikowano najbardziej istotne czynniki wptywajace na liczbę i skutki wypadków drogowych. Niniejszy referat prezentuje wyniki wstepne szerszego programu prac badawczych dotyczacych bezpieczeństwa ruchu drogowego na obszarach województw.

Słowa kluczowe: regiony, bezpieczeństwo ruchu drogowego, czynniki wpływu, modelowanie 


\section{Introduction}

In the literature on road safety the numerous factors that may affect the state of safety on the roads are analysed. Part of the analyses concern the areas of whole countries, others are limited to specific road sections and intersections. Few works are devoted to road safety in the regions. It is very important because the region is a basic level of management in the European Union.

Ten years ago the European Union adopted the document titled "The EU Transport Policy for 2010 - Time to decide", which established a goal of $50 \%$ fewer deaths in 2010 [2]. The III European Action Programme for Road Safety defined the strategy of the actions [3]. The programme aimed to:

- Encourage road users to the correct behaviour on the roads,

- Improve vehicle safety,

- Improve road infrastructure.

Joining the European Union in 2004 Poland pledged to implement this programmme and adopted its own Road Safety Programme for the years 2005 - 2007 - 2013 GAMBIT 2005 [8] which aimed to half the number of road accident fatalities in the years 2003 - 2013. The programme assumed five strategic objectives:

- construction of road safety system,

- development of safe behaviour of road traffic participants,

- protection of pedestrians and cyclists,

- building and maintaining a safe infrastructure,

- reduction of accident severity.

Important action proposed to undertake within the framework of the second strategic objective was to improve the behaviour of road traffic participants through:

- reducing the share of traffic participants travelling under the influence of alcohol by $50 \%$

- reducing the proportion of vehicles exceeding the speed limit by $50 \%$

- increasing the share of traffic participants using safety belts to $95 \%$.

This paper presents the results of analyses designed to verify the accuracy of assumptions adopted in the GAMBIT 2005 Programme [11]. 


\section{The characteristics of the problem}

Based on the study of literature the characteristics of the problem posed by the road users behaviour mentioned above have been presented.

\subsection{Alcohol}

Studies show that alcohol has a significant influence on the drivers' perception and behaviour. It impairs motor coordination, reduces the reaction rate, limits visual field causing incorrect assessment of distance and speed, causes deterioration of visual perception by limiting detail perception.

\section{Alcohol - the share of fatalities}

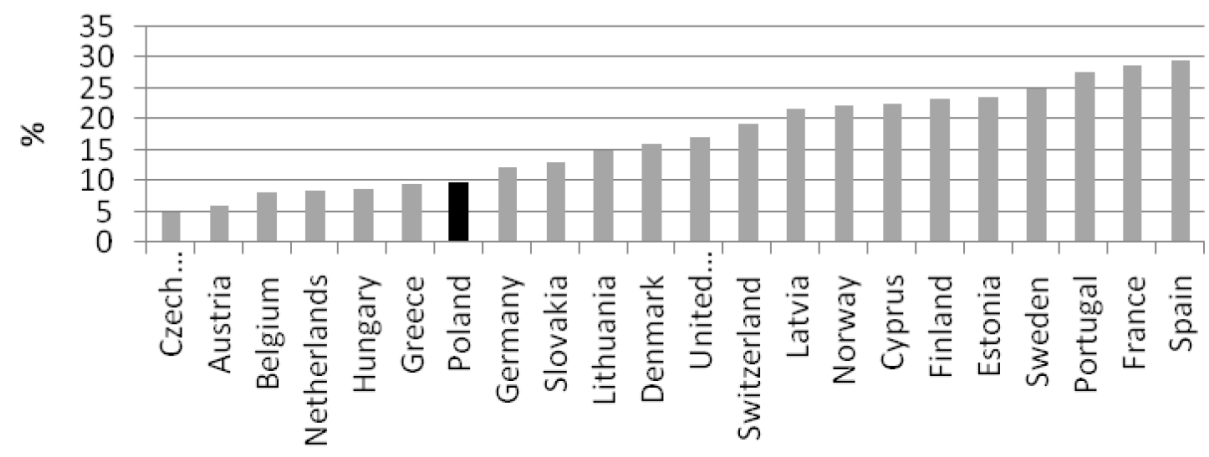

Fig. 1 The share of fatalities in road accidents caused by drivers under influence of alcohol in selected European countries in 2006 [5]

Depending on the country the problem of alcohol in road traffic is different. In 2006, the worst situation was in Spain where up to almost $30 \%$ of fatalities was the result of drunk driving. In the Czech Republic the rate was less than $5 \%$, in Poland almost $10 \%$. As a result of action taken in Poland, the problem significantly decreased (from $24 \%$ in 1994 to $10 \%$ in 2008). The highest number of accidents caused under the influence of alcohol, occurred in Mazowieckie, Śląskie and Malopolskie.

The studies of the literature show that the most effective way to fight drunk driving is a tightening of the law and reducing the permissible blood alcohol concentration limit together with strong surveillance and frequent testing of drivers. [1], [4], [7], [9] [10]. 


\subsection{Speed}

In Poland, approximately $30 \%$ of accidents are caused by excessive speed and severity of accidents related to speeding falls in the range of about 18 fatalities/100 accidents during the day to more than 23 fatalities / 100 accidents at night. [5]

Similarly in other countries, for example in the United States AP in the years 1983-2002 the speed was the cause of 30\% of fatal accidents. In each age group, men predominated in excessive speed, particularly when under the influence of alcohol. The majority of the fatal accidents occurred outside the built-up area. The regional differences in the occurrence of accidents caused by speeding was observed. The Western states were characterised by a higher rate than the eastern states [6].

Studies on Polish territory have shown that, unfortunately, dangerous driving behaviour involving drunk driving or excessing speed limit go hand in hand (Fig. 2). Analyses showed that in general most accidents occurred in Mazowieckie, Wielkopolskie and Śląskie. The same voivodships have the highest rate of accidents due to excessive speed.

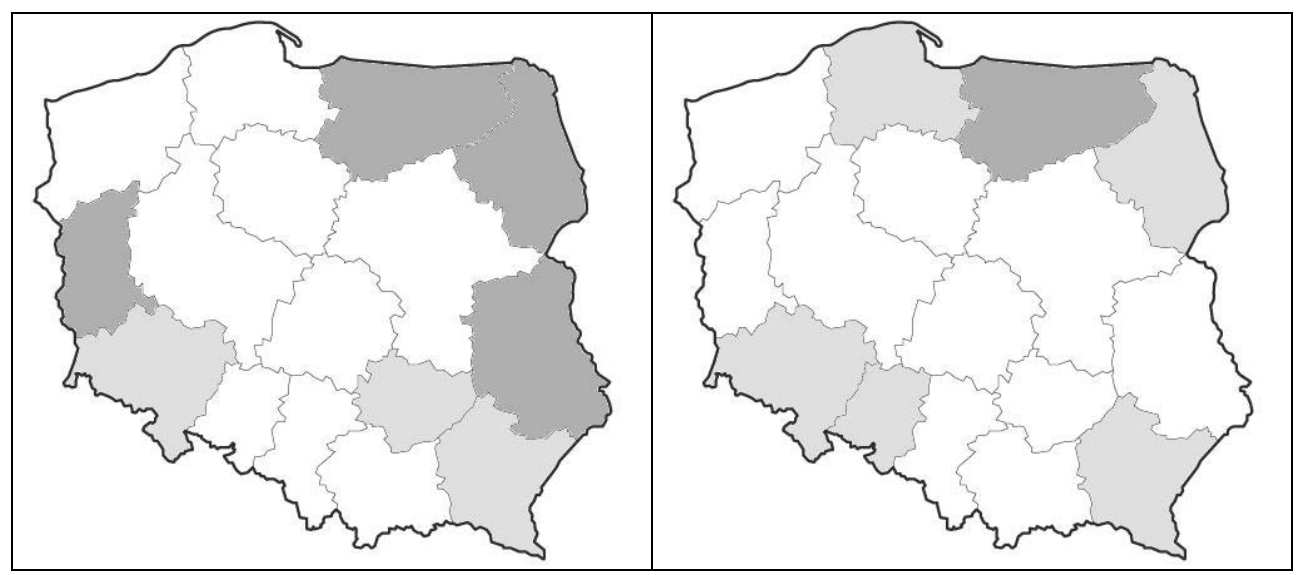

Fig. 2 Classification of voivodships in terms of the rate of accidents caused by drunk driving (left) and excessive speed (right)

The highest risk of accidents caused by drunk driving occurred in the border voivodships such as Warmia-Mazury, Podlaskie, Lubelskie and Lubuskie and Podkarpackie, Świętokrzyskie and Dolnośląskie. The biggest share of accidents due to speeding occurred in the Warmia-Mazury Voivodship (over $26 \%$ of all accidents).

Speeding is a major factor increasing the risk of accidents and therefore it is important to reduce the number of drivers that behave in this dangerous 
way. As in the case of alcohol it is important to introduce law which will be consistently enforced. Many countries have a positive experience after the introduction of more speed cameras and speed research combined with immediate punishment for drivers who exceed speed limits. It should be indicated/stated that speed limits should be applied in a thoughtful way. Furthermore, the development of geometry and environment of the road in a manner that encourages or even forces the reduction of speed is sometimes more effective than installation of speed cameras.

\subsection{Safety belts}

Another important factor affecting mortality and severity of accidents is the use of safety belts. Many reports and studies clearly prove the argument that fastened safety belts, significantly increase road accident participant's chances of surviving or sustaining less serious injuries.

Studies on the effectiveness of safety belts and air bags in reducing the number of fatalities in road accidents have been conducted for many decades, and each of them concludes that safety belts are one of the most effective measures of road safety improvement.

The effectiveness of safety belts and air-bags in reducing the risk of death in the event of an accident is as follows:

- fastened safety belts - risk of death reduced by $42-47 \%$,

- the use of air-bags but the safety belts unfastened - risk of death reduced by $5-13 \%$,

- the use of air-bags and fastened safety belts - risk of death reduced by $47-53 \%$.

Unfortunately, comparative studies prove that Poland in the statistics of safety belts use in 2004 was one of the countries with the lowest rate of safety belt use in Europe (Fig. 3). Front seat passengers and drivers fastened safety belts in approximately $75 \%$ cases while the rear seat passengers in about $50 \%$.

As for activities to increase the use of safety belts, they rely mainly on informative campaigns, often dramatic in their message. Indeed, it is hard to carry out checks. Seeing the check point, the participants will fasten their safety belts. Similarly it is difficult to verify the use of safety belts by accident participants because if they are conscious, knowing about the duty to fasten safety belts they will claim they did. Unfortunately it is difficult to 
determine the precise impact of the use of safety belts on the effects of accidents in Poland, due to a lack of data or high uncertainty on this issue.

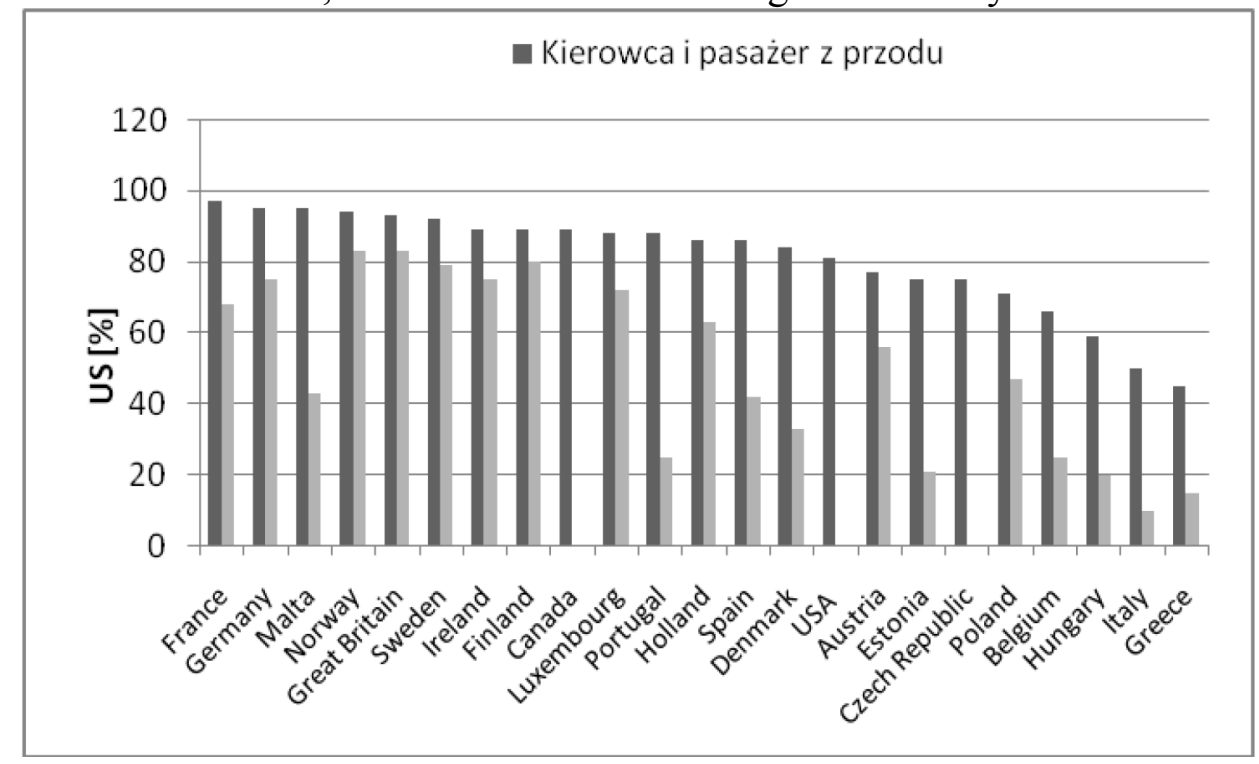

Rys. 3 Stosowanie pasów bezpieczeństwa w samochodach osobowych w wybranych krajach w roku 2004.

\section{Modelling the impact of selected factors of road safety}

The presented analysis shows that it is difficult to define the direct impact of selected factor: alcohol, speed, safety belts on road safety. The difficulty results from the lack of or uncertainty of data on one hand and their strict interdependence on the other. Therefore, modelling was selected as a tool to assess the impact of various factors of road safety.

\subsection{Input data}

The data used for modelling come from the police database SEWIK (data on road accidents) and the tests carried out on behalf of the National Road Safety Council consisting of the study of driver behaviour such as speed and safety belt use [6]. Unfortunately, in Poland frequent testing of drivers in terms of alcohol content in exhaled air are not carried out, and such data are not available. Similarly, there are no reliable data on safety belt use by the victims of accidents. As it has been previously mentioned victims do not admit to not fastening their safety belts. The analysed data come from the years 2000-2004. 


\subsection{Factor identification and the selection of variables}

The database from 16 voivodships from the years 2000-2004 was used for statistical analyses and modelling. For the analysis, the following dependent variables were accepted: the number of accidents LW, the number of victims injured LR, the number of fatalities $\mathrm{LZ}$. The independent variables were: area POW, the population LM, population density GLM, percentage of urban population in the general population ULM, the number of registered unemployed BZ, the number of passenger vehicles LPO, the sale of alcohol ALK, the percentage of people using safety belts UZP, the rate of drivers exceeding the limit speed UVD.

In the first part of the analysis the factor analysis was carried out and the degree of correlation of dependant and independent variables was defined. The analysis of correlation of dependent variables showed that the proportion of people living in cities ULM is strongly correlated with the general number of population LM and the rate of unemployed BZ. Whereas the number of passenger vehicles is strongly correlated to the size of the population. Furthermore, it was found that the most important factors influencing the number of accidents LW, the number of victims injured LR and the number of fatalities LZ as dependent variables are: population LM, the number of passenger vehicles LPO, the number of people living in the city of LMM and the number of unemployed BZ, and ALK alcohol sales, the percentage of people using safety belts UZP, the proportion of drivers exceeding the speed limit UVD.

\subsection{Model selection}

Using the program STATISTICA several models of the dependence of the number of fatalities, the number of victims injured and the number of accidents from the identified factors were examined. The most promising model showing the impact of the analysed factors on the level of losses in road traffic is the model described by the formula 1 . Table 1 compares the parameters of models for particular types of losses.

$$
L X_{k}=L M^{\beta_{1, k} \cdot \exp }\left\{\beta_{2, k} \cdot U V D+\beta_{3, k} \cdot U Z P+\beta_{4, k} \cdot A L K+\beta_{5, k} \cdot T R+\beta_{0, k}\right\}
$$

where:

LX - the level of losses in road traffic,

$\mathrm{LX} 1=\mathrm{LZ}-$ the number of fatalities,

$\mathrm{LX} 2=\mathrm{LR}-$ the number of injured victims,

$\mathrm{LX} 3=\mathrm{LW}-$ the number of road accidents, 
LM - population [mln people],

UVD - the share of vehicles exceeding speed limit [\%],

UZP - the level of safety belt use [\%],

ALK - the level of alcohol consumption [1/mk/year],

TR - the share of through traffic: high -1 , low 0 .

Table 1. Comparison of the parameters of models of level of losses in road traffic - the most important factors

\begin{tabular}{|l|c|c|c|c|c|c|c|c|}
\hline \multirow{2}{*}{ Model } & $\beta_{\mathbf{1}}$ & $\beta_{\mathbf{z}}$ & $\beta_{\mathbf{3}}$ & $\beta_{\mathbf{4}}$ & $\beta_{\mathbf{5}}$ & $\beta_{\mathbf{0}}$ & $\mathrm{p}$ & $\mathrm{R}^{2}$ \\
\cline { 2 - 9 } & $(\mathrm{LM})$ & $(\mathrm{UVD})$ & $(\mathrm{UZP})$ & $(\mathrm{ALK})$ & $(\mathrm{TR})$ & & & \\
\hline LZ & 1,085 & 0,013 & $-0,007$ & 0,035 & 0,253 & 4,337 & 0,0155 & 0,944 \\
\hline LR & 0,990 & $-0,003$ & 0,014 & 0,073 & 0,172 & 5,995 & 0,0285 & 0,952 \\
\hline LW & 1,032 & $-0,004$ & 0,011 & 0,063 & 0,235 & 5,918 & 0,0389 & 0,961 \\
\hline
\end{tabular}

Figures 4 - 6 present the diagrams of the analysed factors influence on the number of fatalities in the voivodships in Poland. Analysing the results it was concluded that:

- the analysed factors significantly affect the number of fatalities in road accidents in the voivodship LZ,

- the number of fatalities LZ grows in proportion to the increase in: population LM, the proportion of speeding UVD and the level of alcohol consumption in the voivodship ALK,

- the number of fatalities LZ decreases in proportion to the increase in the level of use of safety belts in the vehicle UZP.

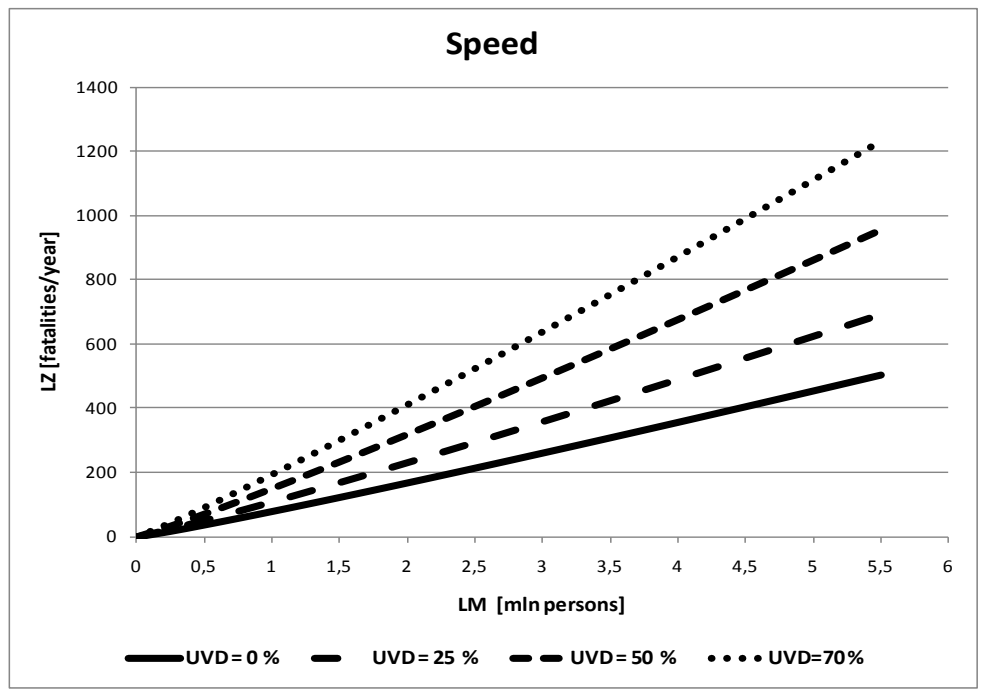

Fig. 4 Influence of the population LM and rate of vehicles exceeding the speed limit UVD on the number of fatalities $L Z$. 


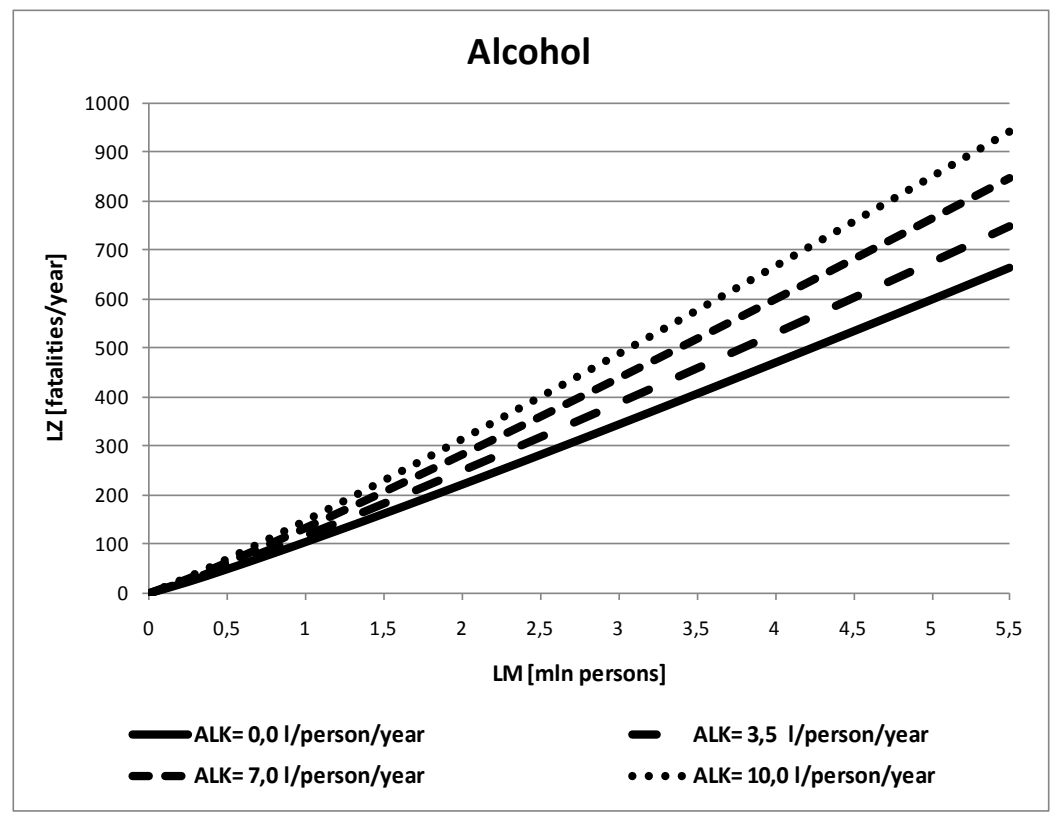

Fig. 5 Influence of the population LM and the level of alcohol consumption ALK on the number of fatalities $L Z$.

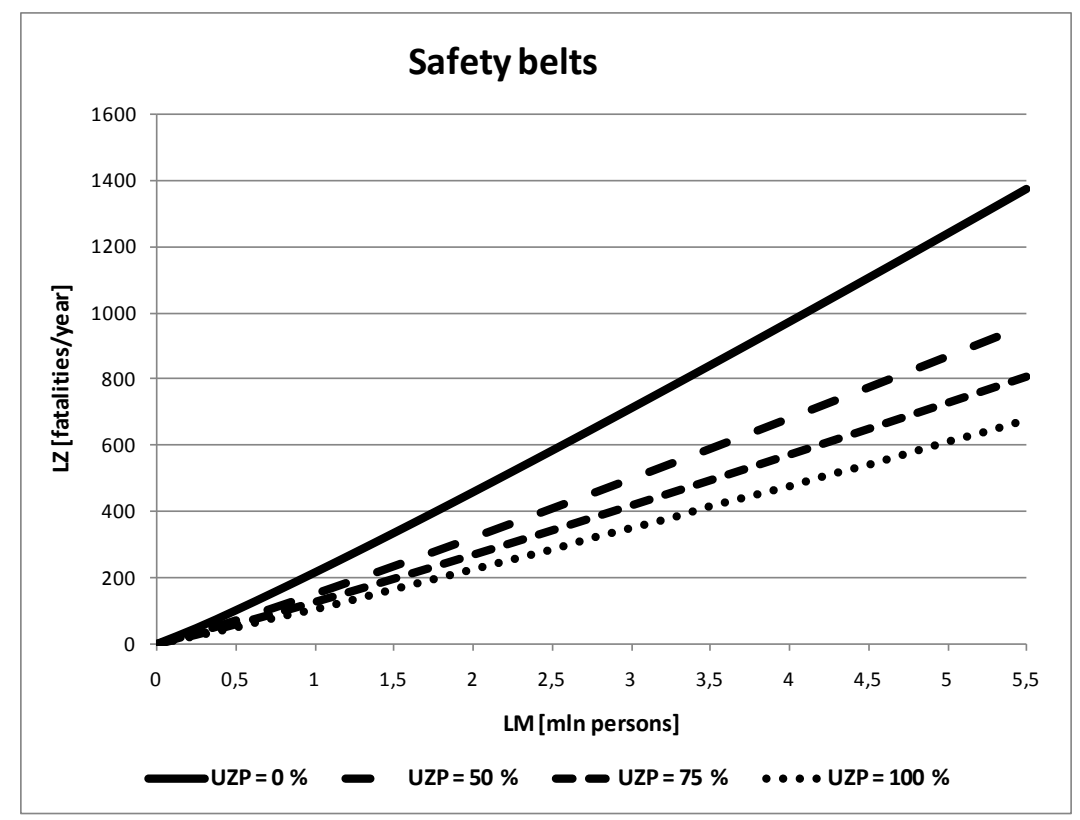

Fig. 6 Influence of the population LM and the level of safety belts use UZP on the number of fatalities $L Z$. 
The developed model was used to estimate the number of fatalities LZ in different voivodships depending on the interventions undertaken. Summing up the results obtained from the individual viovodships, an estimate of the number of fatalities for Poland was prepared, as shown in Figure 7.

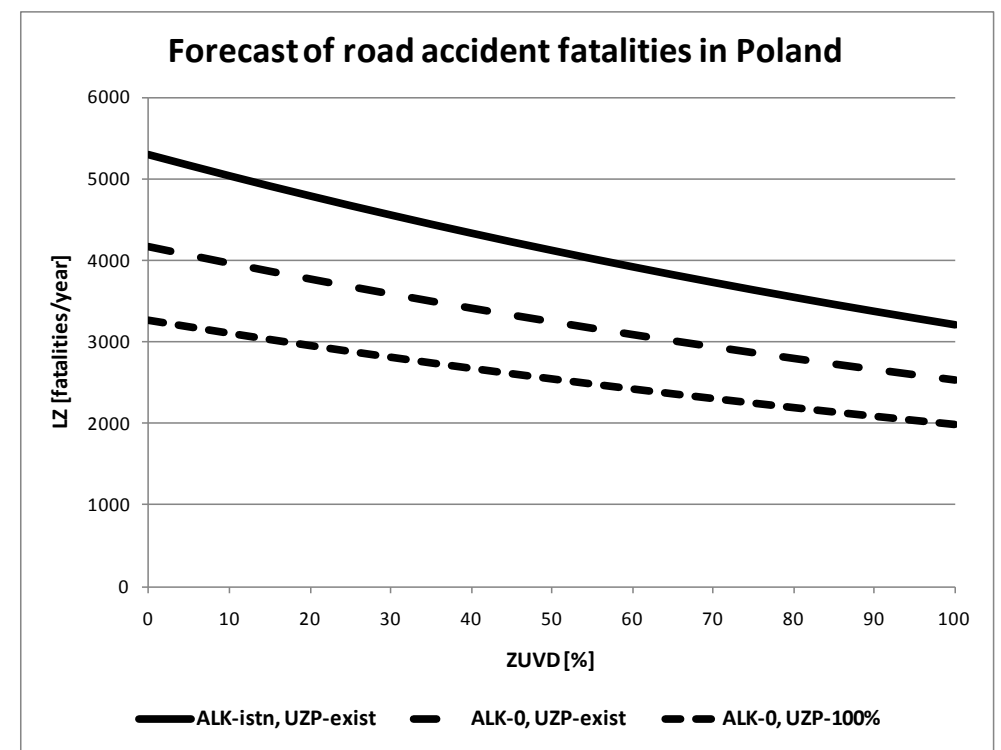

Fig. 7 Estimate of the number of fatalities for Poland depending on the level of undertaken interventions.

Analysing the obtained results it was stated that:

- undertaking resolute actions on road safety in the form of: reducing the proportion of vehicles exceeding the permitted speed limit, reducing alcohol consumption, increasing the use of safety belts can substantially affect the reduction of the number of traffic fatalities.

- reducing to zero the contribution of vehicles exceeding the speed limit and the level of alcohol consumption and increasing to a maximum $(100 \%)$ the level of seat belts use would reduce the number of fatalities from 5400 to 1975 , i.e. by 3425 victims

- contribution of individual factors in reducing the number of fatalities would be as follows:

- $64 \%$ - reducing to zero the rate of vehicles exceeding the speed limit,

- $20 \%$ - reducing to zero the rate of alcohol consumption,

- $16 \%$ - increasing to a maximum (100\%) the level of safety belt use 


\section{Summary}

The material presented indicates the important role of modelling the number of accidents and accident casualties in road traffic. The developed models can be used to predict the loss in traffic, depending on the used set of interventions, and to choose the most effective measures for road safety.

The conducted analyses have shown that the strategic actions aimed at changing behaviour of traffic participants can bring a significant effect on reducing the number of fatalities in road accidents. The reduction in the number of drivers exceeding the speed limit can bring the biggest effect. Effects of an automatic surveillance system used in France, as well as the deployment of about 1,000 speed cameras in Poland confirm this thesis. Also actions to increase the use of safety belts and the reduction of alcohol consumption can contribute to a significant reduction in the number of fatalities in road accidents in Poland.

\section{Literature :}

[1]. Blomberg, R. Lower BAC limits for youth: Evaluation of the Maryland .02 law (DOT HS 806 807). Washington, DC: U.S. Department of Transportation 1992

[2]. European Commission, White Paper - European transport policy for 2010: time to decide. Luxembourg: Office for Official Publications of the European Communities 2001, ISBN 92-894-0341-1.

[3]. European Road Safety Action Programme. Halving the number of road accident victims in the European Union by 2010: A shared responsibility. Commission of the European Communities. Brussels.

[4]. James C. Fell, Robert B. Voas.(2006)The effectiveness of reducing illegal blood alcohol concentration (BAC)limits for driving: Evidence for lowering the limit to .05 BAC. Journal of Safety Research 37,233243

[5]. Gaca S.(2008): Zarządzanie prędkościa pierwszoplanowym środkiem poprawy Brd na drogach krajowych. Konferencja Gambit 2008.

[6]. Gaca S., Jamroz K., Ząbczyk K. i inni, (2006): Ogólnokrajowe studium pomiarów prędkości pojazdów i wykorzystania pasów bezpieczeństwa. $\mathrm{W}$ ramach SPOT. Raport Okresowy nr 2. Konsorcjum: SIGNALCO Kraków - TRAFIK Gdańsk - BIT Poznań.. Kraków - Gdańsk Poznań.

[7]. Hingson, R., i inni (1992). Reduced BAC limits for young people (impact on night fatal) crashes. Alcohol, Drugs and Driving, 7(2), 117-127 
[8]. Jamroz K. i inni: Krajowy Program Bezpieczeństwa Ruchu Drogowego na lata 2005-2007-2013 GAMBIT 2005. BRD 4/2005

[9]. Jamroz K.: Rola pasów bezpieczeństwa I metody badań ich stosowania. Transport Samochodowy vol. 3, 2006, pp. 21-54.

[10]. Research and Evaluation Associates [REA]. (1991). The effects following the implementation of an 0.08 BAC limit and an administrative per se law in California (DOT HS 807 777). Washington, DC: National Highway Traffic Safety Administration.

[11].Wachnicka J., Jamroz K.: Koncepcja metody zarzadzania na obszarach jednostek administracyjnych. Praca niepublikowana, Projekt ZEUS, Raport - Politechnika Gdańska, Katedra Inżynierii Drogowej. Gdańsk 2009.

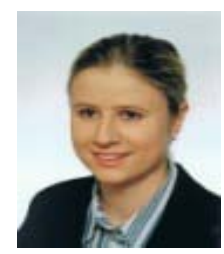

Joanna Wachnicka Master of Eng. Gdansk University of Technology, Highway Engineering Department, specialization: transportation and traffic engineering, road safety.

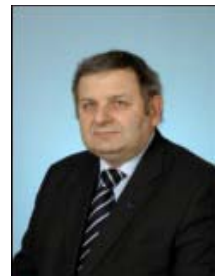

Kazimierz Jamroz PhD Eng. Gdansk University of Technology, Highway Engineering Department, specialization: transportation and traffic engineering, road safety, intelligent transport systems 